\title{
Struma Ovarii: A Report of Two Cases
}

\section{Struma Ovari: İki Olgu Sunumu}

\author{
Funda Atalay ${ }^{1}$, Gülay Bilir Dilek², Kadir Çetinkaya ${ }^{1}$ \\ ${ }^{1}$ Dr.A.Y. Ankara Onkoloji Eğitim ve Araştırma Hastanesi, Kadın Hastalıkları Bölümü, Ankara, Türkiye \\ ${ }^{2}$ Dr.A.Y. Ankara Onkoloji Eğitim ve Araştırma Hastanesi, Patoloji Kliniği Ankara, Türkiye
}

Dergiye Ulaşma Tarihi:10.05.2017 Dergiye Kabul Tarihi:30.06.2017 Doi: 10.5505/aot.2017.44366

\section{ÖZET}

Struma ovari, yumurtalık dermoid tümörlerinin nadir görülen bir varyantı olup, tiroid doku komponentleri başlıca bileşenidir. Cerrahiden önce teşhis koymak zordur. Bu makalede, 2 adet struma ovari vakası bildirilmektedir. Birincisi 41 yaşında kronik pelvik ağrı sendromlu hasta salpingo-oferektomi ile tedavi edilmişti. İkinci hasta ise postmenopozal kadında total abdominal histerektomi, bilateral salphingo-ooferektomi uygulanmıştı. En son patolojik tanıları, tipik morfolojik kriterlere ve immün boyamaya dayanan struma ovari idi.

Anahtar Kelimeler: Teratom, struma ovari, tiroid

\begin{abstract}
Struma ovarii is a rare variant of dermoid tumors of the ovary in which thyroid tissue components is the major constituent. It is difficult to make a diagnosis before surgery. The current study reports 2 cases of struma ovary. The first case was a 41 year-old patient with chronic pelvic pain, treated with salpingo-oophorectomy. The second case was a postmenopausal woman treated with total abdominal hysterectomy bilateral salpingo-oophorectomy. The final pathological diagnoses were struma ovarii based on typical morphologic criteria and immune staining.

Keywords: Teratoma, struma ovarii, thyroid
\end{abstract}

\section{Introduction}

Struma ovarii is a rare ovarian tumor that has been reported to represent $1 \%$ of all ovarian tumors and 3 to $5 \%$ of all dermoid tumors of ovary (1-2). Struma ovarii is the most common type of monodermal teratoma, to be classified as a struma ovarii, teratoma must be composed predominantly of mature thyroid tissue $(>50 \%)$ (3). It predominantly occurs between 30-50 years of age, most often in the unilateral ovary, and occasionally in combination with contralateral ovary mature teratoma and cystadenoma (4). As it is a rare tumor, there has been controversy about its diagnosis and also treatment. We present two cases of struma ovarii in this report.

\section{Case 1}

A 41 year-old female patient (gravida: 3, para: 3) was admitted to gynecology department with complaints of pelvic pain. She has normal menstrual periods. Her medical history included a thyroid nodule $(12 \times 11 \mathrm{~mm})$ a year before, which had been biopsied and report as a nodular hyperplasia but her thyroid functional tests were normal. Her gynecological examination revealed a large right adnexial mass. Transvaginal ultrasonography revealed a $15 \mathrm{~cm}$ right ovarian tumor composed of multilocular cysts. Tumor markers were in normal ranges (CEA 0, Ca15-3 23.7 U/ml; Ca19-9 $6.73 \mathrm{U} / \mathrm{ml}$; Ca125 $15 \mathrm{U} / \mathrm{ml}$; ßhCG 0; AFP $1.4 \mathrm{ng} / \mathrm{ml}$ ). Exploratory laparotomy was performed. Peroperatively nearly $15 \mathrm{~cm}$ a multicystic mass in right ovary was seen, uterus and left ovary and tube were normal. There was no ascites. Right salpingo-oophorectomy was performed and intraoperative frozen section was reported as benign tumor. Macroscopic pathologic examination revealed a tumor $15 \times 8 \times 6 \mathrm{~cm}$ in size and reported as struma ovarii, monodermal teratoma immunhistochemically positive staining with tyroglobulin and TTF-1. Figure1. Postoperative period was uneventful. After the pathologic diagnosis of struma ovarii, thyroid tests were performed and all were reported as 
normal. Follow-up examinations every 4-6 months were planned and at time of writing, there was no problem with the patient.

\section{Case 2}

A 70 year-old postmenopausal women presented with an ovarian tumor, which was identified during routine medical check-up for menopause. Her medical history with this tumor began 6 months before the surgery. A 20x11 $\mathrm{mm}$ simple cyst with thin septum in left ovary seen with transvaginal ultrasound, Ca 125 was $12.0 \mathrm{U} / \mathrm{ml}$. Then she was called for control 3 months later. There was no difference in the first control and then she was controlled 3 months later, too. But as the cyst persists MRI was performed. MRI showed 27x20 mm septated cyst in left ovary with positive contrast substance in peripheral wall of the cyst. Ca125 was within normal ranges. The patient underwent a total abdominal hysterectomy with bilateral salpingo-oophorectomy (TAH+BSO). Intraoperatively frozen-section biopsy reported struma ovarii. The final histopathological examination was also reported as struma ovarii and immune histochemical positive staining with tyroglobulin and TTF-1. During the patients follow up no complications occurred.

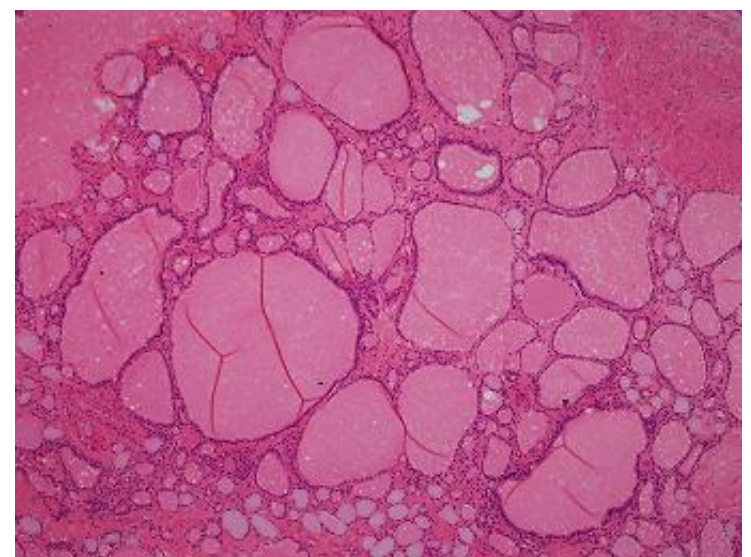

Figure 1: Photomicrograph of struma ovarii- clearly showing thyroidal acini lined with low cuboidal epithelium and filled with colloid along with ovarian stromal tissue. X100 H-E.

\section{Discussion}

Struma ovarii is a rare benign form of ovarian germ cell tumor which is a monodermal teratoma and composed of mature thyroid tissue (more than 50\%). It occurs in reproductive age group $(4,5)$. According to the previous studies, patients with struma ovarii are largely without symptoms, or are accompanied by non-specific symptoms like as abdominal pain, palpable adnexial mass, abnormal vaginal bleeding with ascites and hydrothorax $(6,7)$.

The ultrasonographic findings of struma ovarii are nonspecific; there are multilocular cysts with solid components with different signals from high to low on MRI (6).

It is not easy to diagnose struma ovarii preoperatively. The diagnosis can be managed intraoperatively via frozen section or postoperatively pathologically. It is possible to have a diagnosis for struma ovarii preoperatively, if patients have hyperthyroidism and ovarian mass but only 5-8\% of patients with struma ovarii have thyroid hyperfunction. It has been recommended that thyroid function tests be analyzed in the presence of symptoms and signs related to thyroid hyperfunction $(4,7,8)$.

Surgical management is the treatment option for struma ovarii. Conservative surgery is recommended for patients desiring fertility. Ovarian cystectomy or salpingo-oophorectomy seems to be optimal. For postmenopausal women or after completion of childbearing TAH+BSO is recommended. $(2-4,8)$.

In conclusion, struma ovarii is a rare condition which the diagnosis is difficult because of clinical manifestations or imaging studies as the presenting clinical features are widely diverse. Conservative surgery (cystectomy or USO) in childbearing age and definitive treatment (TAH+BSO) in postmenopausal is sufficient for struma ovarii. Standard surgical follow up is sufficient and the prognosis is excellent.

Financial disclosure: We did not receive financial support for this article.

Conflict of interest: In the article, there is no conflict of interest in any.

\section{References}

1. Wee JYS, Li X, Chern BSM, Chua ISY. Struma ovarii: management and follow-up of a rare ovarian tumour. Sing Med J 2015; 56:35-39. 
2. Shanthi E, Parimala, Chander RV, Jayashree, Sulochana S. Ovarian struma - report of a rare case. J Clin Diagn Res. 2015 Apr;9(4):QJ01.

3. Yücesoy G, Cakiroglu Y, Muezzinoglu B, Besnili B, Yucesoy I. Malignant struma ovarii: a case report. J Korean Med Sci. 2010 Feb;25(2):327-9.

4. Qiao PF, Gao Y, Niu GM. Struma ovarii accompanied by mature cystic teratoma of the other ovary: A case report and literature review. Oncol Lett. 2015 May;9(5):2053-2055.

5. Sinha NK. Struma ovarii with elevated ca-125 levels and ascites mimicking advanced ca ovary. J Clin Diagn Res. 2014 Mar;8(3):140-1.

6. Nurliza Binti Md Nor, Kusumoto T, Inoue S, Nakamura K, Seki N, Hongo A, Kodama J, Hiramatsu Y. Three cases of struma ovarii underwent laparoscopic surgery with definite preoperative diagnosis. Acta Med Okayama. 2013;67(3):191-5.

7. Yoo SC, Chang KH, Lyu MO, Chang SJ, Ryu HS, Kim HS. Clinical characteristics of struma ovarii. J Gynecol Oncol. 2008 Jun;19(2):135-8.

8. Tanimanidis P, Chatzistamatiou K, Nikolaidou A, Kaplanis K. Struma ovarii. A case report. Hippokratia. 2014 Oct-Dec;18(4):357-8. 